\title{
Work Motivation and Supervisor Performance in Indonesia
}

\author{
Muhammad Alkirom Wildan \\ Researcher, Management Department, Faculty of Economics and Business, \\ University of Trunojoyo Madura, Bangkalan, Jawa Timur, Indonesia \\ E mail: wildan.alkirom69@gmail.com
}

\begin{abstract}
Company or organization requires specific ways to improve the ability of employees between in ways that are giving them motivation to keep them more active in doing their jobs, but it also empower the company to its employees. This study aims to determine how much influence the employee empowerment and work motivation on the performance of supervisors. The approach used in this study is a quantitative approach using analytical tools in the form of multiple regression analysis with 130 samples. The results showed that employee empowerment partially affected the performance of supervisors, and partially work motivation affected the performance of supervisors. The test simultaneously produced that all independent variables of employee empowerment and work motivation had positive and significant effects on the performance of supervisors. The dominant variable influences to employee performance are employee empowerment.
\end{abstract}

Keywords — Employee Empowerment; Work Motivation; Employee Performance.

\section{Introduction}

The progress of the company or organization is certainly supported by employee performance. Someone can be said to have a good performance if they can carry out their work well, namely by achieving goals according to standards set by performance appraisal, in other words performance appraisal will encourage employees to compete for awards, bonuses, or be promoted to more positions well. For employees to maximize their ability to achieve their goals, a company or organization needs certain ways to support them. Among the ways that can be done by a company or organization is to give them motivation so that they are more active in doing their work. In addition to motivation, employees also need to be empowered so that they have the ability, have clear authority, and have accountable responsibilities. The employee empowerment program should be run first to announced any problems that will be faced. If the employee empowerment process is in progress, it is important to monitor the development and assess the results because the evaluation is an evaluation of performance. To empower subordinates, managers must trust the capabilities and commitments of members of their organizations.

The Women's Employee empowerment and Family Planning Agency (BPPKB) has three fields, namely the field of women's employee empowerment, the field of family planning, and the field of community welfare. In the era of Regional Autonomy, supervisors face increasingly difficult challenges and problems in carrying out their duties and functions, especially in the implementation of population programs, family planning and family development in the field, where community behavior changes towards more advanced conditions in all fields as at the insistence of changes that occur. Such as changes in the structure of government, technological progress, outlook on life, culture and community values, quality services, and so forth.

BPPKB has supervisor employees who are widespread in every district in Indonesia. The distribution area is not evenly distributed, in each district there are about four to eight supervision agents. This is less effective because in a sub-district they have to hold several villages as their target area. The distribution of instructors depends on the size of the area. Large areas need supervisor's more than small areas.

The lack of available supervisors makes the organization have to work hard so that the organization's goals can be achieved. There is a need for coordination with each region to succeed the organization's goals. The BPPKB cannot recruit the counselors themselves because they have been arranged by their superiors. So in the field of counseling, inevitably the BPPKB must be able to succeed the program that will be run by utilizing existing supervisors. For existing FEA can work optimally, then they should make efforts to maintain their existence in a way to empower them.

Efforts are still low to empower families to realize quality small families; lack of communication, information and family planning and family welfare education services; the high number of families who have not been able to fulfill their basic needs to a minimum; the still low durability and quality of the family environment; the high unmet need (unmet family planning needs) as quoted from the BPPKB Renstra in Indonesia in the period 2010-2015 (20-23) shows that the employee empowerment and motivation carried out by the BPPKB are still lacking. From the description above, the writer is interested in conducting research to find out whether employee empowerment and 
work motivation affect the performance of Indonesia Supervision Board of Women Employee empowerment and Family Planning counselors partially or simultaneously, and also to find out, which of the employee empowerment and work motivation variables that influence dominant.

\section{Literature Review}

\subsection{Employee Empowerment}

Employee empowerment comes from the word power, which means power, that is, the ability to make it happen or not at all. (Suwatno, 2011). Mulyadi in Kadarisman (2012), employee employee empowerment is to enable and provide opportunities for employees to plan, implement plans, and control work plans for which they are responsible. In relation to the implementation of regional autonomy, the better employee empowerment of the apparatus will improve the performance of the apparatus. This is in accordance with the 6 benefits of employee empowerment:

- Improve quality, innovation, loyalty, sense of achievement and employee productivity.

- Increase creativity and commitment of employees.

- One important aspect for the success of the transition from bureaucratic organizations to team- based organizations.

- Improve service to customers.

- An important tool for improving performance through the dissemination of decision making and responsibility because it encourages employee involvement.

- Can realize, support, encourage, and help develop the potential contained in individuals so that they become independent humans but still have personality.

Many organizations fail to improve because managers who have the power to make changes do not care about the problem at hand. Meanwhile, people who are at the forefront, who understand the problem, do not have the authority to do something. Often an organization pays consultants handsomely to tell them how to improve the work process, even though their subordinates can do it.

To obtain optimal results regarding employee empowerment according to Handoko and Tjiptono (in Hendayady, 2011), five strategies are needed as follows:

- No Discretion, describes a very routine and repetitive task. The employee did not participate in designing the work. Monitoring is also left to others. Thus, there is no decision-making authority related to job content and job context.

- Task Setting, ie employees are given full responsibility for decisions on job content and little responsibility for job context. Employees are empowered to make decisions about the best way to complete the tasks assigned. In this case management sets the mission and goals, while employees are empowered to work their best way to make it happen.

- Participatory Employee empowerment, where employees are involved in part of decision making on job content and job context. They are involved in problem identification, alternative development, and alternative recommendations in job content. They are also involved for the same activities in decision making related to job context.

- Mission Defining, where employees are empowered to decide on the job context only.

- Self-Management, namely giving authority to employees.

\subsection{Work Motivation}

Motivation is the impetus for a series of human behavior processes to achieve goals (Wibowo, 2011). If businesses want to grow and develop must create a work environment where everyone wants to do their best ( ILO, 2013) theory of motivation that is commonly used to explain the source of motivation at least be classified a two, which is a source of motivation within (intrinsic) and a source of motivation from the outside (extrinsic).

- Intrinsic motivation is motives that become active or functioning need not be stimulated from the outside, because in every individual there is already an urge to do something. Individual factors that usually encourage someone to do something are: a) Interest, someone will feel compelled to do an activity if the activity is an activity that suits their interests; b) A positive attitude, someone who has a positive attitude towards an activity willingly to carry out an activity, and will try his best to complete the activity concerned as well as possible; c) Needs, everyone has certain needs and will try to do any activity as long as the activity can meet their needs. Simon devung in Suwatno (2011)

- Extrinsic motivation is active and functioning motives due to external stimuli. According to Herzberg in Suwatno (2011) there are two main factors in organizations that make employees feel satisfied with the work done, and that satisfaction encourages them to work better, namely: a) Motivator, namely work performance, appreciation, responsibility given, opportunities to develop themselves and their work; dab b) Occupational health factors, constitute good company policy and administration, supervision of adequate technicians, satisfying salaries, good working conditions, and work safety.

Based on the opinion of Mc. Clelland and Edward Murray, it can be stated that the characteristics of managers who have high achievement motivation include:

- Have a high level of personal responsibility

- Dare to take and accept risk

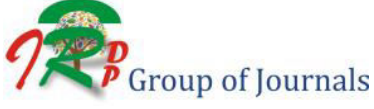


- Have realistic goals

- Having a comprehensive work plan and striving to realize goals

- Utilize concrete feedback in all the activities carried out

- Looking for an opportunity to realize the plan has been programmed.

\subsection{The Performance}

Every company wants good employee performance. For this reason, employees are required to improve performance to assist the company in developing productivity in order to achieve company goals. Performance according to Riniwati (2011) is a combination of ability, effort and opportunity that can be accessed from her work. Performance is the result of work quality and quantity achieved by an employee in carrying out his function according to the responsibilities given to him (Masram and Mu'ah, 2017).

\subsection{Framework}

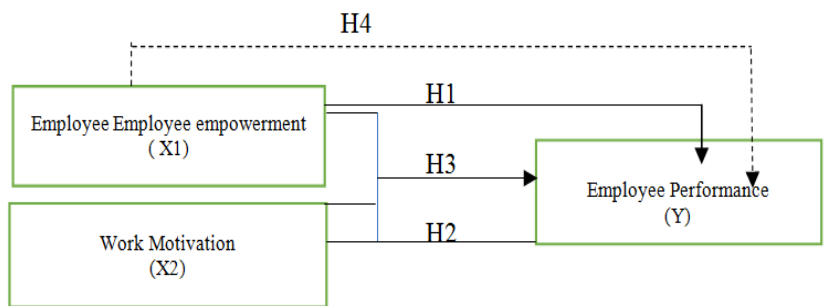

Fig. 1: Research Framework

\section{Hypothesis}

H1: Partially the employee empowerment variable has a significant effect on the performance of supervisor in Indonesia.

$\mathrm{H} 2$ : Partially, work motivation variable has a significant effect on the performance of supervisor in Indonesia.

H3 : Simultaneously the employee empowerment and work motivation variables have a significant effect on the performance of supervisor in Indonesia.

$\mathrm{H} 4$ : Employee empowerment variable is suspected to have a dominant effect on the performance of supervisor in Indonesia.

\section{Research Methodology}

\subsection{Object of Research}

This research took place in one of the bodies in the Indonesia, precisely in the Agency for Employee empowerment of Women and Family Planning (BPPKB) Indonesia.

\subsection{Research Approach}

This type of research in this research is quantitative research. This study aims to test a theory or hypothesis in order to strengthen or even reject the theory or hypothesis of existing research results. According to Sugiyono (2010) quantitative data is data in the form of numbers in accordance with its shape; quantitative data can be processed or analyzed using statistical calculation techniques.

\subsection{Definition of Variable Operations}

The Operational Definition explains the specification of the independent variable $(\mathrm{X})$, which is the effect of employee empowerment and work motivation and the dependent variable $(\mathrm{Y})$, which is performance to impose limits on the scope of research and clarifies the measurement of research variables.

\subsection{Independent Variable - Employee Empowerment}

Indicators p emberdayaan according to Said in Hendayady (2011), it is necessary to apply a work ethic and value solutions in staffing by one using the basic approach of professionalism values are as follows:

- Knowledge

- Has a Copyright

- Renewal

- Intellectual Honesty

- To be responsible

- Do not take sides

\subsection{Work Motivation}

Indicators according to McClelland's theory, Lunthans in Suwatno (2011) say that motivational indicators are:

- Successfully complete the task

- Solve complex problems

- Maintaining a harmonious relationship

- Accepted as part of a group or team

- Influencing people to change attitudes or behavior

- Control people and activities

\subsection{Dependent Variable}

The indicators to measure performance in work behavior according to government regulation no. 46 year 2011 article 4 are as follows:

- Quantity

- Quality

- Period of time

- Cost

- Service orientation

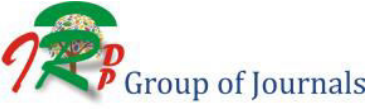


- Integrity

- Commitment

- Discipline

- Cooperation

- Leadership

The indicators for each of the variables above are measured by a Likert rating scale which has four (4) levels of preference preferences which each have a score of 1-4 with the following details:

4 = Strongly Agree

$3=$ Agree

$2=$ Disagree

$1=$ Strongly Disagree

\subsection{Population and Sample}

The population in this study amounted to 130 samples and the population is all family planning counselors who are spread in each district Indonesia.

Data collection method - Data collection techniques were carried out using the following methods: direct interview techniques, questionnaire techniques, and observation techniques.

Data analysis method - The analysis used in this study is to use multiple regression analysis by first conducting a validity test, reliability test, classic assumption test and hypothesis test.

\section{Discussion}

Validity test - Validity test is used to measure the validity or validity of a questionnaire (Ghozali, 2013).

a) Validity Test of Employee empowerment Variables (X1).

Based on the results of data processing, the $\mathrm{P}$ variable validity test can be seen in the table below:

Table 1. Validity Test of Employee empowerment Variables (X1)

\begin{tabular}{|c|c|c|c|c|}
\hline No & Statement & r-count & r-table & Information \\
\hline 1 & X1.1.1 & 0.469 & 0.261 & Valid \\
\hline 2 & X1.1.2 & 0.554 & 0.261 & Valid \\
\hline 3 & X1.2.1 & 0.443 & 0.261 & Valid \\
\hline 4 & X1.2.2 & 0.416 & 0.261 & Valid \\
\hline 5 & X1.3.1 & 0.323 & 0.261 & Valid \\
\hline
\end{tabular}

\begin{tabular}{|c|c|c|c|c|}
\hline 6 & X1.3.2 & 0.319 & 0.261 & Valid \\
\hline 7 & X1.4.1 & 0.442 & 0.261 & Valid \\
\hline 8 & X1.4.2 & 0.400 & 0.261 & Valid \\
\hline 9 & X1.5.1 & 0.302 & 0.261 & Valid \\
\hline 10 & $\mathrm{X} 1.5 .2$ & 0.345 & 0.261 & Valid \\
\hline 11 & $\mathrm{X} 1.6 .1$ & 0.442 & 0.261 & Valid \\
\hline 12 & $\mathrm{X} 1.6 .2$ & 0.580 & 0.261 & Valid \\
\hline
\end{tabular}

The tabulation results Correlation Value for each statement item has a value of $r$ count $>r$ table. Thus based on the validity test shows that on all items the statement on the employee empowerment variable is declared valid and can be used as an research instrument.

b) Test the Validity of Variables in Work Motivation (X2)

Based on the results of data processing, then the validity test of work motivation variables can be seen in the following table:

Table 2. Test the Validity of Work Motivation Variables (X2)

\begin{tabular}{|c|c|c|c|c|}
\hline No & Statement & r-count & r-table & Information \\
\hline 1 & $\mathrm{X} 2.1 .1$ & 0.500 & 0.261 & Valid \\
\hline 2 & $\mathrm{X} 2.1 .2$ & 0.504 & 0.261 & Valid \\
\hline 3 & $\mathrm{X} 2.2 .1$ & 0.378 & 0.261 & Valid \\
\hline 4 & $\mathrm{X} 2.2 .2$ & 0.534 & 0.261 & Valid \\
\hline 5 & $\mathrm{X} 2.3 .1$ & 0.504 & 0.261 & Valid \\
\hline 6 & $\mathrm{X} 2.3 .2$ & 0.438 & 0.261 & Valid \\
\hline 7 & $\mathrm{X} 2.4 .1$ & 0.324 & 0.261 & Valid \\
\hline 8 & $\mathrm{X} 2.4 .2$ & 0.465 & 0.261 & Valid \\
\hline 9 & $\mathrm{X} 2.5 .1$ & 0.276 & 0.261 & Valid \\
\hline 10 & $\mathrm{X} 2.5 .2$ & 0.369 & 0.261 & Valid \\
\hline 11 & $\mathrm{X} 2.6 .1$ & 0.468 & 0.261 & Valid \\
\hline 12 & $\mathrm{X} 2.6 .2$ & 0.580 & 0.261 & Valid \\
\hline
\end{tabular}

The tabulation results Correlation Value for each statement item has a value of $r$ count> $r$ table. Thus, the validity test shows that on all items of the statement on the variable work motivation is declared valid and can be used as research instruments.

c) Test the Validity of Performance Variables (Y)

Based on the results of data processing, the validity test variable $\mathrm{k}$ inerja can be seen on $\mathrm{t}$ abel following: 
Table 3. Test the Validity of Performance Variables (Y)

\begin{tabular}{|c|c|c|c|c|}
\hline No & Statement & r-count & r-table & Information \\
\hline 1 & Y1.1 & 0.293 & 0.261 & Valid \\
\hline 2 & Y1.2 & 0.270 & 0.261 & Valid \\
\hline 3 & Y2.1 & 0.299 & 0.261 & Valid \\
\hline 4 & Y2.2 & 0.415 & 0.261 & Valid \\
\hline 5 & Y3.1 & 0.364 & 0.261 & Valid \\
\hline 6 & Y3.2 & 0.433 & 0.261 & Valid \\
\hline 7 & Y4.1 & 0.394 & 0.261 & Valid \\
\hline 8 & Y4.2 & 0.276 & 0.261 & Valid \\
\hline 9 & Y5.1 & 0.275 & 0.261 & Valid \\
\hline 10 & Y5.2 & 0.364 & 0.261 & Valid \\
\hline 11 & Y6.1 & 0.363 & 0.261 & Valid \\
\hline 12 & Y6.2 & 0.349 & 0.261 & Valid \\
\hline 13 & Y7.1 & 0.318 & 0.261 & Valid \\
\hline 14 & Y7.2 & 0.350 & 0.261 & Valid \\
\hline 15 & Y8.1 & 0.354 & 0.261 & Valid \\
\hline 16 & Y8.2 & 0.587 & 0.261 & Valid \\
\hline 17 & Y9.1 & 0.405 & 0.261 & Valid \\
\hline 18 & Y9.2 & 0.437 & 0.261 & Valid \\
\hline 19 & Y10.1 & 0.286 & 0.261 & Valid \\
\hline 20 & Y10.2 & 0.371 & 0.261 & Valid \\
\hline
\end{tabular}

The tabulation results Correlation Value for each statement item has a value of $r$ count $>r$ table. Thus, the validity test shows that all statement items on the performance variable are declared valid and can be used as research instruments.

Reliability Test - Reliability is a tool to measure a questionnaire which is an indicator of a variable or construct (Ghozali, 2013: 47). The results of the reliability testing are as follows:

Table 4. Reliability Test Results

\begin{tabular}{|c|c|c|c|}
\hline Variable & Cronbach Alph & Criteria & Information \\
\hline $\begin{array}{c}\text { Employee empowerment } \\
(\mathrm{X} 1)\end{array}$ & 0.718 & 0.70 & Reliable \\
\hline Work Motivation $(\mathrm{X} 2)$ & 0.726 & 0.70 & Reliable \\
\hline Performance (Y) & .709 & 0.70 & Reliable \\
\hline
\end{tabular}

Based on the table above it can be seen that all research variables have Cronbach alpha values greater than 0,70 so that it can be concluded that all variables used in this study are reliable.

\section{Classic Assumption Test - Normality test}

\section{Normal P-P Plot of Regression Standardized Residual}

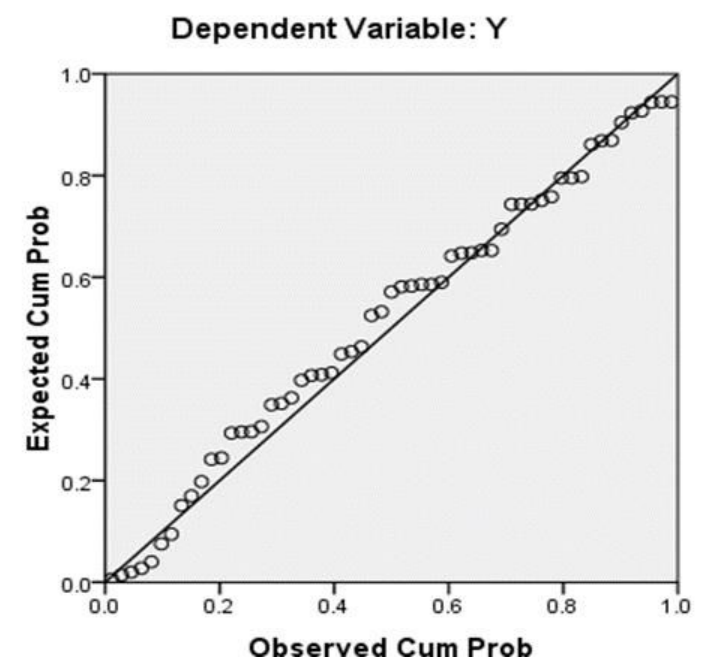

Fig.2: Normality Test Results

Based on the picture of the normal probability plot, it is seen that the points spread around the diagonal line and follow the direction of the diagonal line, then the regression model meets the normality assumption.

Multicollinearity Test - The results of multicollinearity test in this study can be seen in the following table:

Table 5. Multicollinearity Test Results

\begin{tabular}{|l|l|l|l|l|}
\hline No & Variable & \multicolumn{2}{|l|}{$\begin{array}{l}\text { Collinearity } \\
\text { Statistics }\end{array}$} & Information \\
\cline { 3 - 4 } & & Tolerance & VIF & \\
\hline 1 & $\begin{array}{l}\text { Employee } \\
\text { empowerment } \\
(\mathrm{X} 1)\end{array}$ & 0.823 & 1.216 & $\begin{array}{l}\text { Multicollinearity } \\
\text { free }\end{array}$ \\
\hline 2 & $\begin{array}{l}\text { Work Motivation } \\
(\mathrm{X} 2)\end{array}$ & 0.823 & 1.216 & $\begin{array}{l}\text { Multicollinearity } \\
\text { free }\end{array}$ \\
\hline
\end{tabular}

Based on the table above illustrates that the results of the calculation of tolerance values indicate there are no independent variables that have a tolerance value of less than 0.10 which means there is no correlation between the independent variables. The results of the calculation of the value of the variance inflation factor (VIF) also showed the same thing: there is not one independent variable that has a VIF value of more than 10 . So it can be concluded that there is no multicollinearity between the independent variables in the regression model. 
Heteroscedasticity Test - According to Ghozali, (2013) the heteroscedasticity test aims to test whether in the regression model there is an inequality of variance from residual safety to other observations.

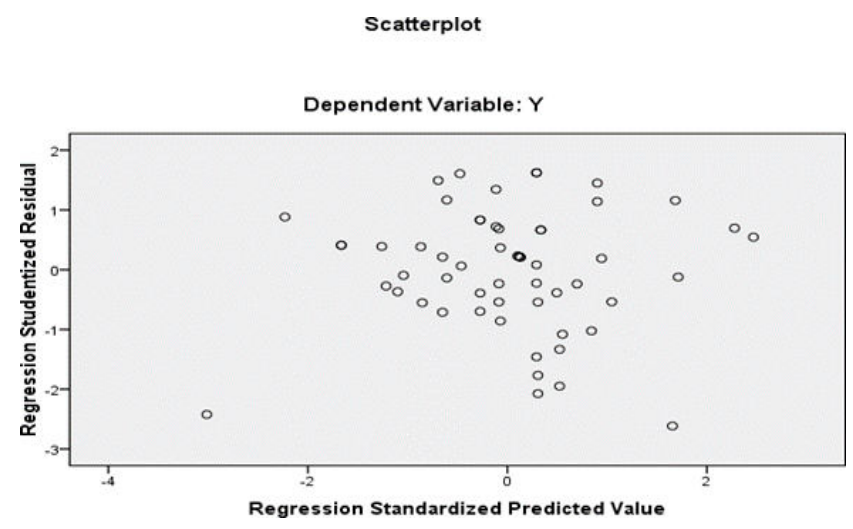

Fig. 3: Heteroscedasticity Test Results

Based on the scatterplot image above, it can be seen that the points spread randomly and are spread both above and below the number 0 on the $\mathrm{Y}$ axis. It can be concluded that there is no heteroscedasticity in the regression model, so that the regression model is suitable for performance based on input of independent variables work employee empowerment and motivation.

Hypothesis test - Hypothesis testing is done by looking at the effect of each independent variable on the dependent variable simultaneously ( $\mathrm{F}$ test), and partially ( $\mathrm{t}$ test).

Determination Coefficient Test - The results of the multiple determination coefficients can be seen in the following table:

Table 6. Coefficient of Determination $R$ and $\mathbf{R}^{2}$

\begin{tabular}{|l|c|r|l|l|}
\hline Model & $\mathrm{R}$ & $\mathrm{R}$ Square & $\begin{array}{l}\text { Adjusted R } \\
\text { Square }\end{array}$ & $\begin{array}{l}\text { Std. Error of the } \\
\text { Estimate }\end{array}$ \\
\hline 1 & $0.622 \mathrm{a}$ & .386 & .364 & 3.29785 \\
\hline
\end{tabular}

Based on the table above it is known that the coefficient of determination (R2) is obtained at 0.364 . This means that variable X1 (Employee empowerment) and variable X2 (Work Motivation) have a significant effect on the $\mathrm{Y}$ variable (Performance), while the remaining 63.6\% is influenced by other variables not examined in this study.

Furthermore, the results of the calculation of the multiple correlation coefficient (R) of 0.622 or $62.2 \%$ means that, this means that the variables of employee empowerment and work motivation have a strong level of relationship with the performance of supervisors at the
Women's Employee empowerment Agency and Indonesia Planning Board.

$F$ test - The results of the $\mathrm{F}$ test are seen in the following table:

Table 7. F-Test Results (Simultaneous)ANOVAb

\begin{tabular}{|l|l|l|l|l|c|l|}
\hline \multicolumn{2}{|c|}{ Model } & $\begin{array}{l}\text { Sum of } \\
\text { Squares }\end{array}$ & Df & Mean Square & F & Sig. \\
\hline 1 & Regression & 369,687 & 2 & 184,843 & 16,996 & \multirow{2}{*}{000 a } \\
\cline { 1 - 5 } & Residual & 587,296 & 54 & 10876 & & \\
\cline { 1 - 5 } & Total & 956,982 & 56 & & & \\
\hline
\end{tabular}

Hypothesis:

$\mathrm{H}_{0}$ : The variables of employee empowerment and work motivation simultaneously have no significant effect on the dependent variable, namely the performance of supervisors.

$\mathrm{H}_{\mathrm{a}}$ : The variables of employee empowerment and work motivation simultaneously have a significant effect on the dependent variable, namely the performance of supervisors.

Judging from the significant effect using the $\mathrm{F}$ test at a significant level of $(\alpha=0.05)$ from the table above, obtained Fcount of 16.996 with a probability level of 0,000 (significant) and obtained $\mathrm{F}$ table of 2,66 , indicating that the F count is greater than F table (16.996> 2.66) means that $\mathrm{Ho}$ is rejected $\mathrm{H} 1$ is accepted and because the probability is much smaller than 0.05 , the regression model can be used to predict performance. Or it can be said that employee empowerment and work motivation together affect performance. Then it can be stated a hypothesis which states that the independent variable consisting of employee empowerment (X1) and work motivation (X2) simultaneously affect the dependent variable namely the performance of the instructor $(\mathrm{Y})$ can be accepted or proven.

$T$ test (partial) - $\mathrm{T}$ test results can be seen in the following table:

Table 8. t-Test Results (Partial)

\begin{tabular}{|c|c|c|c|c|}
\hline Independent Variable & $\mathrm{t}$ & Sig. & Information & Results \\
\hline (Constant) & 4,167 & 0.005 & & \\
\hline $\begin{array}{c}\text { Employee } \\
\text { empowerment (X1) }\end{array}$ & 3,187 & 0.002 & Significant & Proven \\
\hline Work Motivation (X2) & 3,085 & 0.003 & Significant & Proven \\
\hline
\end{tabular}

Based on the $\mathrm{t}$ test table, it can be explained for each independent variable as follows: 
Employee empowerment (X1)

Hypothesis

$\mathrm{H}_{0}$ : Employee empowerment variable does not have a positive and significant effect on the dependent variable, namely the performance of supervisors.

$\mathrm{H}_{\mathrm{a}}$ : The employee empowerment variable has a positive and significant effect on the dependent variable, namely the performance of supervisors.

The coefficient value of the employee empowerment variable above shows a coefficient value of 3.187 with a significant level of 0.002 . The significance value is 0.002 $<0.05$ then $\mathrm{H} 0$ is rejected and $\mathrm{H} 1$ is accepted, so it can be concluded that the employee empowerment variable has a positive and significant effect on the dependent variable, namely the performance of supervisors.

\section{Work Motivation (X2)}

Hypothesis

$\mathrm{H}_{0}$ : Work motivation variable does not have a positive and significant effect on the dependent variable, namely the performance of supervisors.

$\mathrm{H}_{\mathrm{a}}$ : The variable of work motivation has a positive and significant effect on the dependent variable, namely the performance of supervisors.

The coefficient value of the work motivation variable above shows the coefficient value of 3.085 with a significant level of 0.003 . The significance value is 0.003 $<0.05$, so $\mathrm{H} 0$ is rejected and $\mathrm{H} 1$ is accepted, so it can be concluded that the work motivation variable has a positive and significant effect on the dependent variable, namely the performance of supervisors.

Multiple Regression Analysis - Based on calculations using the SPSS 16 program, the results are as shown in the following table:

Table 9. Calculation of Multiple Linear Regression Analysis

\begin{tabular}{|c|c|c|c|c|c|c|c|c|}
\hline & \multirow{2}{*}{ Model } & \multicolumn{2}{|c|}{$\begin{array}{l}\text { Unstandardize } \\
\text { d Coefficients }\end{array}$} & $\begin{array}{c}\text { Stand } \\
\operatorname{ardize} \\
\mathrm{d} \\
\text { Coeffi }\end{array}$ & \multirow[b]{2}{*}{$\mathrm{T}$} & \multirow{2}{*}{ Sig. } & \multicolumn{2}{|c|}{$\begin{array}{c}\text { Collinearity } \\
\text { Statistics }\end{array}$} \\
\hline & & B & $\begin{array}{c}\text { Std. Err } \\
\text { or }\end{array}$ & Beta & & & $\begin{array}{l}\text { Toler } \\
\text { ance }\end{array}$ & VIF \\
\hline 1 & $\begin{array}{c}\text { (Consta } \\
\text { nt) }\end{array}$ & $\begin{array}{c}30,03 \\
9\end{array}$ & 7,209 & & 4,167 & .000 & & \\
\hline & X1 & .5221 & .164 & .375 & 3,187 & .002 & .823 & 1,216 \\
\hline & $\mathrm{X} 2$ & .484 & .157 & 363 & 3,085 & .003 & .823 & 1,216 \\
\hline
\end{tabular}

Based on the calculation figures in table, the resulting regression equation is:

$Y=\alpha+\beta 1 X 1+\beta 2 X 2+e$

$Y=30,039+0.521 X 1+0.484 X 2+e$

30,039 : Constants

$0.521+0.484:$ Coefficient / Slope / Sensitivity

$\mathrm{X}_{1}$ : Employee empowerment

$\mathrm{X}_{2}$ : Work Motivation

$\mathrm{Y}$ : Performance

e : Error

Based on the regression equation above, it can be explained as follows.

- The constant value indicates a value of 30,039, meaning that if the value of the independent variable consisting of employee empowerment and work motivation is 0 , then the dependent variable is the performance of supervisors at the Women's Employee empowerment and Family Planning Agency of Indonesia will continue to increase by 30,039 .

- The employee empowerment variable has a positive value with a coefficient or slope value of 0.521 . This means that the relationship of employee empowerment variables with the performance of supervisors has a linear relationship or directly proportional meaning that if the employee empowerment variable has an increase of 1 unit, provided that the other independent variables are of constant value, then the dependent variable namely the performance of the instructor has increased by 0.521 units. Conversely, if the employee empowerment variable decreases by 1 unit, the performance variable of supervisors at the Women's Employee empowerment Agency and Family Planning District of Indonesia has decreased by a coefficient value with the assumption that the other variables have not changed (fixed).

- Work motivation variable has a positive value with a coefficient or slope value of 0.484 . This means that the relationship between work motivation variables and the performance of instructors has a linear relationship or is directly proportional, meaning that if the work motivation variable increases by 1 unit, with the other independent variables being constant, the dependent variable, namely the performance of the instructor, experiences an increase of 0.484 units. Conversely, if the work motivation variable decreases by 1 unit, the performance variable of supervisors at the Indonesia Women's Employee empowerment and Family Planning Agency has decreased by a coefficient value with the assumption that the other variables have not changed (fixed).

\section{d) Discussion}

The Effect of Employee empowerment and work motivation on the Performance of Supervisors - Based on the results of hypothesis testing and regression analysis, it

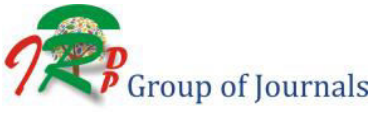


shows that the employee empowerment and work motivation variables together have a significant positive effect on the performance of the supervision staff of the Indonesia Women's Employee empowerment and Family Planning Agency. The results of this research support the previous research conducted by Arifin, A. et al. (2014) showed that the variables of employee empowerment and work motivation together had a significant positive effect on performance. The results were the same was done by Tielung, J. (2013) showed that the variables of employee empowerment and motivation to work together significant positive effect on performance.

Effect of Employee empowerment on the Performance of Supervisors- Based on the results of hypothesis testing and regression analysis, it shows that the employee empowerment variable has a significant positive effect on the performance of the supervision agency of the Women's Employee empowerment and Family Planning Indonesia. The results of this study support previous research Yag conducted by Suryadewi, AP indicates that the variable employee empowerment significant positive effect on performance. The same results are also found in research conducted by Setyawan Suprihono ( 2017) showing that the employee empowerment variable has a significant positive effect on performance.

Effect of Work Motivation on the Performance of Supervisors- Based on the results of hypothesis testing and regression analysis showed that the variable of work motivation has a significant positive effect on the performance of the supervision staff of the Indonesia Women's Employee empowerment and Family Planning Agency. The results of this study support previous research Yag conducted by Juniantara, IW and Riana, IG (2015) show that job motivation significant positive effect on performance. The same research results were conducted by Ekhsan, M. (2019) that work motivation has a significant positive effect on performance. Employees who have high motivation will try their best in each of their work, besides those employees are also interested in improving their ability so that employee performance will increase.

\section{e) Conclusion}

Based on the analysis and the results of the discussion, the following conclusions can be drawn:

- The employee empowerment variable has a significant positive effect on the performance of supervisors.

- Work motivation variable has a significant positive effect on the performance of supervisors.

- Based on the results of simultaneous testing, there was a significant influence between the employee empowerment independent variable (X1) and work motivation $(\mathrm{X} 2)$ on the dependent variable, namely the performance of supervisors (Y) as indicated by the calculated $\mathrm{F}$ value $>\mathrm{F}$ table.

- The employee empowerment variable has a dominant influence on the performance of supervisors.

\subsection{Suggestion}

Based on the analysis and conclusion, the suggestions that researchers can provide are as follows:

- To the leaders, both central and regional leaders, to maintain what has been the responsibility of their respective jobs and to maintain the performance and quality of the work of supervisors that have been implemented.

- For supervisors, it is better to maintain honesty in reporting work results, always work hard in completing their respective tasks, and never delay work so that the quality of work is maintained well.

- Both leaders and supervisors can receive criticism and suggestions from colleagues or the community so that they can improve themselves and can support success in their work.

- For further research, the scope should be expanded again, both in terms of variables, research methods, especially in terms of data collection techniques, the number of populations and samples, as well as the research object used.

\section{Reference}

[1] Arifin, A. et al.. ( 2014 ). The Effect of Employee empowerment and Motivation on Employee Performance (study of the employees of CV. Catr Perkasa Maunggal). Journal of Business Administration. 8 ( 2 ).

[2] Ekhsan, M. ( 2019 ). Effect of Work Motivation and Discipline on Employee Performance. Journal of Economics and Entrepreneurship. 13 ( 1 ).

[3] Ghozali, Imam. ( 2013 ). Multivariate Analysis Application with the IBM SPSS 21 Program. Semarang: Doponegoro University Publisher Agency.

[4] Government Regulation No. 46 of 2011 concerning Performance Evaluation of Civil Servants' Work Performance.

[5] Hendayadi, Agus. ( 2011 ). Employee empowerment of Regional Apartments (Theoretical Study of Regional Apparatus Performance). Journal of Political Science and Government. 1 ( 1 ).

[6] ILO.(2013). Human Resource Management for Successful Cooperation and Business. Jakarta: ILO.

[7] Juniant ara, IW and Riana, IG ( 2015 ). Effect of Motivation and Job Satisfaction on Employee Performance of Cooperatives in Denpasar. E-Journal of Economics and Business.

[8] Kadarisman, M. (2012).Human Resource Development Management. PT. RajaGrafindoPersada: Jakarta.

[9] Masram and Mu'ah, ( 2017 ). Management of Professional Human Resources. Sidoarjo: Zifatama Publisher.

[10] Permanasari, R. (2013). Effect of Motivation and Work Environment on the Performance of PT. AnugrahRaharjo Semarang. Management Analysis Journal, 2 (2).

[11] Potu, A. (2013). Leadership, motivation, and work environment influence on employee performance at the Regional Office of the Directorate General of Suluttenggodan North Maluku State Assets in Manado. EMBA Journal. 1 (4). 
[12] Rahmawati, NH, (2016). Effect of Compensation and Work Experience on Employee Performance. Journal of Management Science and Research. 5 (4).

[13] Riniwati, Harsuko. ( 2011 ). Boosting Motivation and Performance: HR Employee empowerment Approach. Malang: UB Press.

[14] Sofian, E. and Julkarnain (2019). The Effect of Work Experience and Work Spirit on Employee Performance at PT. Dutagriya Sarana Medan.

[15] Sugiyono (2010). Qualitative Quantitative Methods and $R \& D$. Bandung: Alfabeta

[16] Sunyoto, D. ( 2013 ) Human Resource Management. Jakarta: Center For Academic Publishing Service.

[17] Suprihono, S. ( 2017 ). The Effect of Self-efficacy and Employee empowerment on Employee Performance with Organizational Commitment Mediation. Journal of Economics and Business, 12 ( 24 ).

[18] Suryadewi, PC ( 2014 ). The Effect of Employee Employee empowerment on Employee Performance at PT. Bali Segara Nusantara. Journal of Economic Education. 4 ( 1 )

[19] Suwatno and DoniJuniPriansa, (2011). HR Management in Public and Business Organizations. Alfabeta: Bandung.

[20] Tielung, J. ( 2013 ). Employee Employee empowerment, Motivation, and Organizational Commitment to Employee Performance at PT. PLN (Persero) Region VII Manado. EMBA Journal. 1 ( 4 ).

[21] Wirawan, KE et al (2019). Effect of Education Level and Work Experience on Employee Performance. Journal of Management. 5 (1). 